\title{
O direito à comunicação e os desafios da regulação dos meios no Brasil
}

\author{
Camilo Vannuchi' \\ I- ECA - USP \\ São Paulo (SP), Brasil
}

Resumo: Neste artigo, o autor apresenta uma breve revisão do conceito de comunicação como direito humano, fundamentado no debate a cerca do "direito de comunicar" inaugurado pela UNESCO nos anos 1970. Em seguida, à luz de certas características do mercado de comunicação brasileiro consideradas obstáculos à garantia daquele direito (oligopólios, concentração, propriedade cruzada...), o autor elenca princípios constitucionais que, apesar de previstos na Constituição Federal de 1988, nunca foram regulamentados. Finalmente, o autor debruça-se sobre propostas em discussão no âmbito institucional, como o projeto de lei de iniciativa popular da Mídia Democrática, criado em 2013, e o debate recente sobre regulação dos vídeos sob demanda, conduzido pela Ancine em 2016, para formular diretrizes a serem buscadas num possível novo marco regulatório.

Palavras-chave: direito à comunicação; direitos humanos; marco regulatório; meios de comunicação; jornalismo.

Abstract: The right to communication and challenges of media regulation in Brazil - In this paper, the author briefly reviews the concept of communication as a human right, based on the debate about the "right to communicate" introduced by UNESCO in the 1970s. Subsequently, in light of certain characteristics of the Brazilian communications market, which are considered obstacles to the guarantee of that right (oligopolies, concentration, cross ownership...), the author lists constitutional principles which, in spite of being envisaged by the Federal Constitution of 1988, have never been regulated. Finally, the author addresses proposals under discussion within the institutional framework, such as the 2013 Democratic Media draft bill proposed by a citizens' initiative $\mathrm{f}$, and the debate about the regulations of videos on demand, led by Ancine in 2016, to formulate guidelines to be pursued within a possible new regulatory framework.

Keywords: right to communicate; human rights; regulatory framework; media; journalism. 


\section{Introdução}

“O Brasil está passando por um período crítico e precisa garantir a preservação dos avanços que alcançou na promoção da liberdade de expressão e do acesso à informação pública ao longo das duas últimas décadas" (NAÇÕES UNIDAS NO BRASIL, 2016). Este alerta foi feito em 24 de junho de 2016 em nota assinada por David Kaye, relator especial das Nações Unidas sobre a Promoção e Proteção do Direito à Liberdade de Opinião e Expressão, e por Edison Lanza, relator especial para a Liberdade de Expressão da Comissão Interamericana de Direitos Humanos da Organização dos Estados Americanos. Ambos demonstravam preocupação com dois episódios recentes. Num dos episódios, interpretado como ameaça à comunicação pública, o Governo Federal do Brasil, então conduzido por um presidente interino (Dilma Rousseff sofreria o impeachment em agosto), exonerou o presidente da Empresa Brasil de Comunicação (EBC), embora o estatuto previsse atuação independente e mandato legal de quatro anos a expirar em 2020. No outro episódio, interpretado como ameaça à liberdade de acesso à informação, o mesmo governo interino optara por transformar a Controladoria Geral da União (CGU) em Ministério da Transparência, Fiscalização e Controle - uma forma, segundo os relatores, de reduzir seu poder fiscalizador e submetê-lo a interferências políticas.

A nota conjunta não teve efeito prático. Laerte Rimoli foi confirmado no lugar de Ricardo Melo na presidência da EBC, ao mesmo tempo em que a CGU concluiu sua metamorfose em ministério. O alerta, no entanto, foi paradigmático ao expor à comunidade internacional uma tensão que, até então, estava circunscrita ao território brasileiro, e também ao explicitar o caráter inegociável dos direitos à informação e à comunicação, ora concebidos como direitos humanos. Ao interpelar o Brasil, ONU e OEA demonstraram estar atentas não apenas à garantia do direito à informação, previsto na Declaração Universal dos Direitos Humanos de 1948, mas também à garantia do direito à comunicação: um direito ainda não positivado, que engloba, entre outros aspectos, a defesa da comunicação pública, o combate à censura e mecanismos de transparência que promovam um fluxo de informação mais equilibrado.

Este artigo se propõe a narrar resumidamente a gênese do direito à comunicação e a analisar de que maneira o tema, proposto nos anos 1970, influenciou a Constituição Federal de 1988, por meio de garantias jamais regulamentadas, e permanece mobilizando discussões no século XXI. Ao mesmo tempo, busca inferir no debate sobre regulação dos meios, não apenas no âmbito das outorgas em radiodifusão ou dos oligopólios de mídia, mas também no que se refere à internet.

\section{Direito à comunicação, direito à informação}

A compreensão da comunicação como direito humano é formulação mais ou menos recente na história do Direito. Tal conceito foi expresso pela primeira vez 
em 1969 ê, na década de 1970, passou a ser discutido no âmbito da Organização das Nações Unidas para a Educação, a Ciência e a Cultura (UNESCO). Desde 2000, vem ganhando ressonância no debate político. Primeiro na União Europeia — onde o Parlamento Europeu aprovou em 2008 uma diretiva, válida em todos os países-membros, estabelecendo limites à publicidade e padrões mínimos de veiculação de conteúdo independente, regional e acessível -, e em seguida na América Latina, onde marcos regulatórios foram aprovados na Argentina (2009), Venezuela (2010), Equador (2013) e Uruguai (2013).

No Brasil, o direito à comunicação foi oficialmente reconhecido pelo Estado em 2009, no Decreto $n^{\circ}$ 7.037, promulgado em 21 de dezembro daquele ano, que instituiu a terceira edição do Programa Nacional de Direitos Humanos (PNDH-3). Sua diretriz número 22 tem o condão de conciliar os conceitos de "comunicação", "informação" e "democracia", e apresentá-los como princípios orientadores da abordagem contemporânea dos direitos humanos. "Garantia do direito à comunicação democrática e ao acesso à informação para consolidação de uma cultura em Direitos Humanos", diz a diretriz. Ao referir nominalmente o "direito à comunicação", o PNDH-3 contribuiu para inaugurar uma nova etapa no debate sobre o tema. Até então, as instituições se referiam, quando muito, ao direito à informação.

Direito à informação, liberdade de opinião e liberdade de expressão são conceitos anteriores. Já em 1946, a Assembleia Geral da ONU adotara a resolução 59, segundo a qual "a liberdade de informação configura um direito humano fundamental e a pedra de toque de todas as liberdades às quais as Nações Unidas se dedicam”2. Em 1948, o direito à informação foi incluído na Declaração Universal dos Direitos Humanos ao lado do direito à liberdade de opinião e expressão. "Todos têm o direito à liberdade de opinião e expressão", diz o artigo 19. "Este direito inclui a liberdade de expressar opiniões sem interferência e de buscar, receber e transmitir informações e ideias por quaisquer meios e sem limitações de fronteiras".

Já o direito à comunicação resultou da percepção de que direito à informação e liberdade de expressão eram conceitos insuficientes para contemplar as garantias necessárias ao exercício da comunicação, ora visto como ato essencial para a dignidade humana e para o pleno desenvolvimento dos indivíduos. Trata-se de um conceito distinto daqueles, embora os tangencie. As leis de transparência, por exemplo, buscam garantir o direito à informação, mas não chegam a interferir na cadeia de produção da comunicação social. O próprio conceito de direito à informação é normalmente percebido como direito

1 O "direito de comunicar" foi enunciado por Jean D'Arcy, então diretor dos Serviços Visuais e de Rádio no Escritório de Informação Pública da ONU, em Nova York, em artigo na revista EBU Review, do European Broadcasting Union (EBU): "Virá o tempo em que a Declaração Universal dos Direitos Humanos terá de abarcar um direito mais amplo que o direito humano à informação, estabelecido pela primeira vez 21 anos atrás no Artigo 19. Trata-se do direito do homem de se comunicar. (apud FISHER, 1982, p. 26).

2 No original: "Freedom of information is a fundamental human right and is the touchstone of all the freedoms to which the United Nations is consecrated". O texto da Resolução 59 pode ser conferido em https://documentsdds-ny.un.org/doc/RESOLUTION/GEN/NR0/033/10/IMG/NR003310.pdf. Acesso em: 9 jan. 2017. 
de ser informado, de receber informação. Coisa distinta é o "direito de comunicar", concebido nos anos 1970. Entre as novidades introduzidas com a difusão do conceito, sobretudo após a publicação do Relatório MacBride (UNESCO, 1980), está o compromisso com a democratização da informação e com a multiplicidade de vozes, entendendo o direito à informação também como a liberdade que toda pessoa tem de produzir informação e ser ouvida, e não somente de consumir informação produzida por outro.

Tomando emprestado o modelo informacional da teoria da comunicação, não basta ao cidadão ser receptor da mensagem: ele deve ser também emissor, e que a comunicação se faça numa via de mão dupla. Essa abordagem relacional da comunicação foi assim justificada por Vera Veiga França:

Vários autores têm contribuído para alargar o conceito de comunicação; adoto aqui, para fins de nossa discussão, uma formulação e uma perspectiva que temos chamado de "relacional", e se expressa na seguinte formulação: a comunicação é um processo de globalidade, em que sujeitos interlocutores, inseridos em uma dada situação, e através da linguagem, produzem e estabelecem sentidos, conformando uma relação e posicionando-se dentro dela. Nesta concepção, a comunicação não é reduzida a uma dinâmica de transmissão, mas é entendida como interação [...] (FRANÇA, 2016, p. 158).

Por extensão, o direito de comunicar implicaria, segundo a UNESCO, a garantia de acesso das comunidades periféricas não apenas à informação produzida no centro (nos países desenvolvidos, no primeiro mundo, no hemisfério Norte), mas, sobretudo, acesso aos meios de produção, para que possam incidir no espaço público.

\section{A contribuição do Relatório MacBride}

Em 1974, a Resolução 4.121 da $18^{a}$ Conferência Geral da UNESCO incumbiu o recém-empossado diretor-geral, o senegalês Amadou-Mahtar M’Bow (1974-1987), de promover estudos a fim de definir o "direito de comunicar" e elaborar um informe sobre o assunto para ser distribuído na conferência seguinte. Em 1976, M’Bow apresentou seu informe e explicou as razões:

Desde a adoção da Declaração Universal dos Direitos Humanos, em 1948, as mudanças tecnológicas adicionaram novas dimensões aos direitos de informação proclamados no Artigo 19. Levaram, por conseguinte, à exigência de um profundo estudo daquilo que agora é denominado Direito de Comunicar. Conforme foi mencionado durante o debate na Conferência Geral, este é um novo conceito. Assinalou-se que a comunicação deveria ser um processo de "mão dupla", envolvendo o direito de informar assim como o direito de estar informado — um diálogo entre pessoas e um livre e equilibrado fluxo de informação entre 
nações. O Direito de Comunicar, concordou-se sobre isso, deve ser usado nas presentes e futuras necessidades de comunicação do homem e deve ser parte integrante das políticas de comunicação formuladas pelos Estados-membros (apud FISHER, 1982, p. 34).

Em 1978, o assunto foi retomado na $20^{\text {a }}$ Conferência Geral da UNESCO, e novamente seu diretor-geral foi instado a "encorajar estudo e discussão em profundidade sobre o conceito do Direito de Comunicar" (FISHER, 1982, p. 35).

Um primeiro encaminhamento foi a criação, em 1977, da Comissão Internacional para o Estudo dos Problemas da Comunicação. Gabriel García Márquez e Juan Somavia representaram a América Latina na comissão, presidida pelo irlandês Seán MacBride, Nobel da Paz de 1974. Os trabalhos do grupo subsidiaram o relatório "Many voices, one world", também conhecido como Relatório MacBride, aprovado por consenso na $21^{\text {a }}$ Conferência Geral da UNESCO, em 1980. Aquele foi, segundo Venício A. Lima, "o primeiro documento oficial de um organismo multilateral que reconhecia a existência de um grave desequilíbrio no fluxo mundial de informação, apresentava possíveis estratégias para reverter a situação e reconhecia o direito à comunicação". (LIMA, 2011, p. 241). Destacamos um trecho:

As falhas e obstáculos que dificultam o processo de comunicação, e que foram descritos no último capítulo, são a prova da falta de relações democráticas. É o grande público, por definição, que tem interesse em mais comunicação, com maior qualidade e mais livre. Garantir que o público faça sua voz ser ouvida e tenha seus desejos satisfeitos implica trazer o espírito da democracia para dentro das comunicações (UNESCO, 1980, p. 166, tradução nossa).

No livro "O direito de comunicar", de 1982, Desmond Fisher narra o processo de elaboração desse conceito no âmbito da UNESCO e introduz o debate sobre o papel dos meios na construção de narrativas - ou, para usar dois conceitos em voga nos anos seguintes, entre discurso hegemônico e contra-hegemônico.

A liberdade de opinião e expressão contida na Declaração Universal dos Direitos Humanos não basta. Ela ressalta mais o conteúdo da comunicação do que o processo de comunicação e sugere um fluxo unidirecional do transmissor ao receptor da comunicação. Formulações ulteriores, tais como "livre fluxo de informação" e o "livre e equilibrado fluxo de informação" se enredaram em considerações ideológicas e frustraram-se os esforços para defini-las. [...] O conceito do direito de comunicar oferece a possibilidade de pôr fim ao impasse. (...) Ele exprime um princípio filosófico mais fundamental e tem aplicação mais ampla do que as formulações anteriores dos direitos de comunicação. (...) É universal. Enfatiza o processo de comunicar mais do que o conteúdo da mensagem. Implica participação. Sugere uma transferência interativa de 
informação. E, subjacente ao conceito, há uma sugestão ética e humanitária sobre a responsabilidade de assegurar uma distribuição global mais justa dos recursos necessários para que a comunicação se torne possível (FISHER, 1982, p. 15-16).

Estudos realizados pela UNESCO retificaram esse diagnóstico e, estimulados pelo contexto de Guerra Fria, ajudaram a incutir certo senso de urgência. "Em todas as sociedades de todos os tempos, informação é poder", afirma Fisher. "Quanto mais pessoas tiverem informação e quanto mais informação as pessoas tiverem, melhor será a sociedade e mais forte sua base democrática“. (FISHER, 1982, p. 19).

O direito à comunicação começa então a se firmar no âmbito internacional, primeiramente como retórica, e, só mais tarde, como lei. O conceito abarca uma série de liberdades relativas à ação comunicativa. São diretrizes do direito à comunicação a garantia de instrumentos que promovam (1) o intercâmbio de informação, (2) entre emissor e receptor e também entre receptor e emissor, (3) com acesso amplo por todos os indivíduos e grupos sociais, independentemente de classe, gênero ou origem, e (4) resguardadas a capacidade de interação, cooperação e direito de influir.

\section{Contrapoder, esfera pública e democracia}

Se a guerra fria e a ameaça constante de censura sob regimes ditatoriais, de direita ou esquerda, fazem erigir na opinião pública uma espécie de ode à liberdade de imprensa nos anos 1980, o debate sobre direito à comunicação aprofunda sua dimensão contestatória a partir dos anos 1990, com base em dois postulados sócio-políticos: (1) a urgência de promover maior acesso aos meios de produção da notícia, ora interditados mais pela concentração de mídia do que pela força do Estado, e (2) a necessidade de garantir canais contra-hegemônicos que contribuam para ampliar a representatividade dos diversos grupos sociais e constituir contrapeso ao discurso da grande mídia, em parte cooptada pelo poder econômico. Como resultado, surge um inesperado distanciamento entre a função social da imprensa e a práxis do jornalismo. "O que constatamos na maioria das democracias é que há um conflito entre a sociedade e os meios de comunicação", escreve Ignacio Ramonet, diretor de redação do Le Monde Diplomatique.

Costumamos pensar que os meios de comunicação são essenciais à democracia, mas, atualmente, eles geram problemas ao próprio sistema democrático, pois não funcionam de maneira satisfatória para os cidadãos. Isso porque, por um lado, se põem a serviço dos interesses dos grupos que os controlam e, por outro, as transformações estruturais do jornalismo - tais como a chegada da internet e a aceleração geral da informação — fazem com que os meios sejam cada vez menos fiáveis ou menos úteis à cidadania (RAMONET, 2013, p. 53).

Na concepção de Ramonet, os meios de comunicação desempenharam o papel de quarto poder desde a origem da imprensa até recentemente, cumprindo a função de 
coibir abusos por parte dos poderes Legislativo, Executivo e Judiciário. A concepção da imprensa como quarto poder, no entanto, já não faria o mesmo sentido.

O quarto poder não está cumprindo sua missão de contrapoder e, além disso, é o único que, no seio da democracia, não admite nenhum tipo de crítica, não admite nenhum tipo de contrapoder. Os poderes estabelecidos numa democracia - como, por exemplo, o partido ou a coligação dominante numa sociedade — têm de suportar uma oposição, que é um contrapoder. (...) Mas quem critica o poder midiático? Em nossas sociedades, ele é o único sem um contrapoder. Portanto, não é democrático (RAMONET, 2013, p. 65-66).

A abordagem remete a uma frase tão espirituosa quanto atual, formulada por Walter Lippmann em 1922. "Minha conclusão é que, para serem adequadas, as opiniões públicas precisam ser organizadas para a imprensa, e não pela imprensa como é o caso hoje" (LIPPMANN, 2010, p. 42). Trata-se aqui de observar os efeitos dos meios de comunicação na perpetuação de uma esfera pública que se mantém em muitos aspectos pouco permeável às demandas das camadas mais periféricas da sociedade, não muito diferente da esfera burguesa concebida por Habermas em 1962.

Habermas concebia a esfera pública como uma rede de cidadãos aptos a debater, julgar e emitir opinião sobre diversos assuntos, de modo a exercer influência política na comunidade. Essa rede, que no início era presencial, formada em salões e cafés literários, estabelece-se a partir do século XVIII com a "mediação da imprensa" (HABERMAS, 2014, p. 175). Seus membros, no entanto, eram necessariamente aqueles que liam, que tinham acesso à informação. Da mesma forma que mulheres e escravos não acessavam a ágora ateniense, a esfera pública de Habermas tem o tamanho da sociedade burguesa ilustrada: "Essa esfera pública continua literária mesmo quando assume funções políticas. A formação é um dos critérios de admissão; a propriedade, o outro" (idem, p. 232).

Em 1992, no livro Direito e democracia, Habermas revisa o conceito de esfera pública e coloca em evidência algo que parecia negligenciar em Mudança estrutural da esfera pública: as desigualdades de posições dentro da esfera pública moderna e a maneira como um cidadão estará sempre em situação de vantagem ou desvantagem em relação a outro. Cristiana Losekann analisou a evolução do pensamento de Habermas em artigo de 2009. Segundo a autora, Habermas observa, em 1992, que certos grupos de interesse usam a esfera pública "para propagar suas ideias e estratégias de poder" e que "certas pessoas têm acesso privilegiado às informações". "Segundo ele, certos atores têm um poder de organização e de recursos maior do que outros", afirma a autora (LOSEKANN, 2009, p. 49).

Os meios de comunicação desempenham papel decisivo como produtores e reprodutores das desigualdades de posições de que falam Habermas e Losekann. Ter acesso privilegiado à mídia implica reforçar um tipo de privilégio semelhante ao do burguês do século XVIII, relegando aos que não têm a mesma oportunidade de acesso um lugar que é 
essencialmente de espectador ou receptor, e não de formulador. Ao longo dos anos 1990, cresce a reivindicação por meios de comunicação que se proponham a democratizar essa esfera pública, criando oportunidades para a efetiva participação popular, sobretudo por meio de processos deliberativos, de discussões coletivas nas quais floresçam políticas públicas e decisões dos poderes executivo e legislativo. Rousiley C. M. Maia analisa o tema no livro Mídia e deliberação (2008).

A deliberação pode ser entendida como uma atividade interativa, envolvendo duas ou mais pessoas que examinam e consideram os argumentos umas das outras sobre determinada matéria. Ocorre diante de uma questão polêmica ou de um problema, numa situação de conflito (MAIA, 2008, p. 27).

Dessa forma, a defesa do direito humano à comunicação no início do século XXI é afeto à defesa de um modelo de participação política que se convencionou chamar de democracia deliberativa, mais permeável às demandas da sociedade.

Na política deliberativa busca-se articular a legitimidade do exercício do poder político com o processo de justificação pública. Espera-se que os representantes justifiquem suas tomadas de decisão e as normas que buscam implementar, cabendo aos cidadãos promover o raciocínio e o julgamento públicos através de uma comunicação tão livre e desimpedida quanto possível (MAIA, 2008, p. 28).

Para que os meios possam assumir esse papel, não bastam a positivação de direitos e o estabelecimento de um novo corpo normativo, tema central deste artigo. Há que se construir uma ética que tenha como cerne a função social dos meios de comunicação. Não obstante, não se muda esse paradigma sem promover mudanças e ajustes no âmbito normativo. E esses ajustes poderiam começar pela regulamentação do que já foi previsto, trinta anos atrás, na Constituição Federal de 1988.

\section{Garantias constitucionais que pouco garantem}

Segundo uma pesquisa feita em 28 países e divulgada em março de $2017^{3}$, o percentual de pessoas que não confiam na mídia superou pela primeira vez o percentual de pessoas que confiam. No Brasil, a confiança caiu de $54 \%$ para $48 \%$ em um ano. Entre os motivos comumente apontados para a crise de credibilidade da mídia estão a falta de identificação com o conteúdo - leitores e espectadores não se sentem representados — e a percepção dos interesses difusos das empresas de mídia. Numa pesquisa de $2013^{4}$,

3 Edelman Trust Barometer 2017, estudo realizado pela agência Edelman Intelligence com base em entrevistas online de 25 minutos feitas com 33 mil pessoas em 28 países entre 13 de outubro e 16 de novembro de 2016. Disponível em https://www.edelman.com.br/propriedades/trust-barometer-2017/. Acesso em: 10 mar. 2017.

4 Pesquisa feita pelo Instituto Patrícia Galvão e pelo DataPopular com apoio da Fundação Ford em setembro de 2013. Resultados disponíveis em http://agenciapatriciagalvao.org.br/wp-content/uploads/2012/05/ pesquisapoderemc.pdf. Acesso em: 10 mar. 2017. 
69\% dos entrevistados disseram acreditar que ser proprietário de uma emissora de rádio ou TV contribui para que um candidato seja eleito; $63 \%$ afirmaram que políticos não deveriam ser proprietários de meios de comunicação. Apenas um em cada três sabe que a Constituição proíbe deputados e senadores de controlar emissoras de rádio e TV, concessionárias de serviço público:

Art. 54. Os Deputados e Senadores não poderão:

I - desde a expedição do diploma:

a) firmar ou manter contrato com pessoa jurídica de direito público, autarquia, empresa pública, sociedade de economia mista ou empresa concessionária de serviço público, salvo quando o contrato obedecer a cláusulas uniformes;

b) aceitar ou exercer cargo, função ou emprego remunerado, inclusive os de que sejam demissíveis "ad nutum", nas entidades constantes da alínea anterior (BRASIL, 2002, p. 52-53).

Embora o artigo seguinte determine a perda do mandato do parlamentar que "infringir qualquer das proibições estabelecidas no artigo anterior", o Art. 54 vem sendo negligenciado no Brasil. Segundo o Instituto de Estudos e Pesquisas em Comunicação (Epcom) $)^{5}, 10 \%$ dos deputados federais (48) e 25\% dos senadores (20) controlavam canais de radiodifusão em 2006. Em 2015, o Ministério Público Federal desencadeou ações contra 32 deputados e oito senadores que eram proprietários ou sócios de concessionárias de rádio ou TV. Até 2017, nenhum deles perdeu o mandato.

O veto ao controle de emissoras de rádio eTV por parlamentares é uma das garantias previstas na Constituição Federal no âmbito do direito à comunicação. Há outras. Já no Título I, Art. 3ㅜ inciso III, o constituinte definiu como objetivo da República Federativa do Brasil "reduzir as desigualdades sociais e regionais". Não se combate desigualdade sem condições plenas de comunicação. Se os canais de comunicação substituíram a ágora ateniense, é por meio deles que a cidadania se expressa e que a esfera pública se forma na atualidade.

A mídia, marcadamente o jornalismo, é hoje o principal substituto da ágora. Telejornais, revistas e homepages estabelecem as tensões e forjam a "agenda" do país. Assim, os pilares da política e da cidadania são edificados sobre o solo arenoso dos meios de comunicação, de modo que, deslizando brevemente para uma reflexão ética acerca do cenário atual e arriscando uma analogia com a disputa pela terra, o que se verifica hoje em relação à comunicação é a urgência de garantir a função social do solo em detrimento da especulação imobiliária.

Voltando ao Título I, Art. $3^{\circ}$ da Carta Magna, que definiu como objetivo "reduzir as desigualdades sociais e regionais", é perceptível a desigualdade entre Sul/Sudeste e

5 Sobre a pesquisa, ver Intervozes: http://www.intervozes.org.br/direitoacomunicacao/?p=21250. Acesso em: 10 mar. 2017. 
Norte/Nordeste no campo da comunicação. No interior e nas áreas ditas periféricas, a radiodifusão é quase toda baseada em conteúdo elaborado na região Sudeste, enquanto centenas de rádios comunitárias aguardam autorização para operar.

Mais adiante, a Constituição Federal retoma elementos da comunicação no Título II, Capítulo I, Art. 5. "É livre a manifestação do pensamento, sendo vedado o anonimato", estabelece o inciso IV, em frontal contradição com a multiplicação de sites criados com o objetivo de difundir conteúdo falso, calunioso ou difamatório sem revelar a autoria. "É assegurado o direito de resposta, proporcional ao agravo, além da indenização por dano material, moral ou à imagem", determina o inciso $\mathrm{V}$, num país em que o próprio direito de resposta não era regulamentado até 2015.

O inciso IX do mesmo artigo $5^{\circ}$ diz que "é livre a expressão da atividade intelectual, artística, científica e de comunicação, independente de censura ou licença", enquanto o inciso X estabelece como "invioláveis a intimidade, a vida privada, a honra e a imagem das pessoas, assegurado o direito a indenização pelo dano material ou moral decorrente de sua violação", ambos princípios desrespeitados com alguma frequência no Brasil.

Ainda no artigo $5^{\circ}$, há outros dois incisos referentes à comunicação:

XIV - é assegurado a todos o acesso à informação e resguardado o sigilo da fonte, quando necessário ao exercício profissional; [...]

XXXIII - todos têm direito a receber dos órgãos públicos informações de seu interesse particular, ou de interesse coletivo ou geral, que serão prestados no prazo da lei, sob pena de responsabilidade, ressalvadas aquelas cujo sigilo seja imprescindível à segurança da sociedade e do Estado (BRASIL, 2002, p. 16-17).

Nenhum deles se verifica na prática. O acesso à informação não é assegurado pelo Estado em todos os momentos, nem para todos. Mesmo após a sanção da Lei da Transparência, em 2011, falta uma regulamentação que defina prazos e processos para seu cumprimento. Tampouco as repartições estão preparadas para o atendimento dessa demanda. Em paralelo, o consumidor de notícias carente de pleno acesso à informação, uma vez que toda difusão de notícia é mediada pelos veículos — sujeita, portanto, às etapas de seleção e edição, conduzida cotidianamente por editores que não encontram qualquer tipo de sanção quando sonegam informação, seja por dolo ou de forma propositada.

No Título VIII, o capítulo V é formado por cinco artigos, do 220 ao 224, dedicados ao tema da comunicação social. Já no parágrafo $5^{\circ}$ do artigo 220 aparece a primeira incoerência: "Os meios de comunicação social não podem, direta ou indiretamente, ser objeto de monopólio ou oligopólio". Novamente, a ausência de regulamentação impede uma definição clara do que seja monopólio ou oligopólio de comunicação no Brasil. O que se sabe é que quatro famílias comandam $85 \%$ das emissoras e retransmissoras de TV no país de acordo com números de 2013 reunidos pela Comissão de Ciência e Tecnologia, Comunicação e Informática da Câmara dos Deputados: Globo (39,6\%), 
SBT (20,2\%), Band (15,3\%) e Record (10,3\%). Sabe-se também que a Globo, em 2009, detinha sozinha $73,5 \%$ do total de receita publicitária movimentada pela TV aberta no Brasil. (LIMA, RABELO, 2015).

Outros abusos econômicos vetados pela legislação brasileira e encontrados nas empresas de mídia são (1) a propriedade cruzada, quando uma família ou grupo controla veículos de comunicação em diferentes plataformas (jornal, rádio, TV); (2) a concentração vertical, quando a mesma empresa detém diferentes etapas da cadeia produtiva (editora, gráfica e empresa de distribuição, por exemplo), e (3) a concentração horizontal, quando empresas se associam e combinam preços a fim de fatiar o mercado e desmontar a concorrência.

Finalmente, destacamos outros dois artigos da Constituição nos quais se nota negligência do poder público. O Art. 221 lista quatro princípios orientadores da atividade de radiodifusão nem sempre cumpridos pelas emissoras, sobretudo de rádio:

Art. 221. A produção e a programação das emissoras de rádio e televisão atenderão aos seguintes princípios:

I - preferência a finalidades educativas, artísticas, culturais e informativas;

II - promoção da cultura nacional e regional e estímulo à produção independente que objetive sua divulgação;

III - regionalização da produção cultural, artística e jornalística, conforme percentuais estabelecidos em lei;

IV - respeito aos valores éticos e sociais da pessoa e da família.

Já o Art. 223 define regras para outorga e renovação das concessões, mas não atribui a nenhum órgão a responsabilidade por aferir a qualidade do serviço. Por fim, determina que o cancelamento da concessão antes do prazo só ocorrerá mediante decisão judicial, e que a não-renovação dependerá de aprovação de, no mínimo, dois quintos do Congresso Nacional, em votação nominal, percentual difícil de obter.

\section{Propostas de regulação}

A finalidade da atividade jornalística não deve ser o lucro nem o favorecimento, implícito ou explícito, de um grupo, instituição, oligopólio ou conglomerado de mídia. É neste sentido que a defesa do reconhecimento da comunicação como direito humano costuma caminhar lado a lado com proposições que ensejem maior diversidade de vozes e maior presença da sociedade civil.

Propostas no âmbito legislativo vêm sendo feitas a fim de superar vazios normativos ou regulamentar princípios constitucionais jamais regulamentados. Parte dessas propostas está hoje sistematizada no Projeto de Lei de Iniciativa Popular da Comunicação Social Eletrônica6. Também conhecido como Projeto de Lei da Mídia Democrática, ele começou

6 A íntegra do projeto pode ser acessada em http://www.paraexpressaraliberdade.org.br/projeto-de-lei/. Acesso em: 10 jan. 2017. 
a ser debatido em 2009, na Conferência Nacional de Comunicação, e foi consolidado em 2011, no âmbito do Fórum Nacional pela Democratização da Comunicação (FNDC), assumindo a forma de um novo marco regulatório da radiodifusão. Sua meta é garantir multiplicidade de vozes, reduzindo a concentração econômica, combatendo os oligopólios e promovendo maior pulverização de emissoras, sobretudo as públicas (entre elas as comunitárias, o que contribui para que mais grupos tenham acesso à produção e difusão de conteúdo).

Se a Constituição estabelece um sistema de complementaridade entre comunicação privada, estatal e pública, o projeto de lei determina que ao menos 33\% dos canais deverão integrar o sistema público, tanto no rádio quanto na TV. O Poder Executivo deverá assegurar que o conteúdo produzido pelo sistema público chegue a 80\% dos municípios. Emissoras que integrarem esse sistema deverão manter um órgão curador composto em sua maioria por representantes da sociedade civil.

O projeto de lei contempla ainda outros temas relevantes para a garantia do direito à comunicação, como um mínimo de 70\% do tempo de programação das emissoras de TV dedicado à produção nacional (Art. 22) e limites à concentração econômica, tais como a determinação de que uma empresa não poderá controlar mais do que cinco emissoras no território brasileiro (Art. 14). Já os pedidos de resposta ganham prazo de 48 horas para serem atendidos, sejam individuais, coletivos ou difusos (Art. 25).

No âmbito da comunicação digital, um marco regulatório foi criado em 2014 sob o título de Marco Civil da Internet. Ele chega a 2017 desatualizado, em especial no que tange à oferta de serviços como TV digital e streaming, ao mesmo tempo em que novos desafios se apresentam, sobretudo na regulação de vídeos sob demanda. A discussão acerca dos vídeos disponibilizados na web foi deflagrada pelo Conselho Superior do Cinema em 2015 e motivou a Agência Nacional do Cinema (Ancine) a publicar uma notícia regulatória em 2016, anunciando a abertura de consulta pública sobre o tema.
A primeira etapa de uma possível regulação passa pela definição de escopo e dos objetivos pretendidos. Em seguida, serão abordadas as obrigações aos agentes econômicos, como as iniciativas voltadas para a promoção do conteúdo nacional e para um modelo de tributação mais adequado a este mercado. (ANCINE, 2016, p. 2).

A migração da TV analógica para a TV digital rompeu com o paradigma da limitação do espectro eletromagnético e permitiu, pela primeira vez, uma ampliação sem precedentes no número de emissoras e rádios comunitárias em atividade, assim como o barateamento da operação. Agora, o país está diante de novas possibilidades de regulação, que organizem e dinamizem, por exemplo, o conteúdo oferecido pelo Netflix, definindo percentual de produção nacional e local, entre outros aspectos: uma iniciativa oportuna num país em que "a proporção de pessoas que acessam vídeos sob demanda ao menos uma vez por dia tenha crescido de cerca de 30\% para mais de 50\% entre usuários de banda larga, de 2010 para 2015." (ANCINE, 2016, p. 2). 


\title{
Considerações finais
}

A comunicação como direito humano mantém-se como objetivo a ser perseguido. Segundo Margarida K. Kunsch, os problemas apontados em 1980 no Relatório MacBride ainda "podem ser encontrados em todas as sociedades" (KUNSCH, 2009, p. 60).

\begin{abstract}
Podemos apontar a violência física e as medidas de intimidação, a legislação repressiva, a censura, a constituição de listas negras de jornalistas [...]. Outros obstáculos se manifestam na forma de pressões econômicas e sociais: monopólios de fato (públicos, privados e transnacionais); infraestruturas inadequadas; e definição restrita do conceito de notícia, dos critérios de publicações e da escolha dos temas a debater, além da insuficiência de formação e de experiência dos profissionais. Tudo isso limita o direito dos cidadãos à informação [...] (KUNSCH, 2009, p. 61).
\end{abstract}

Kunsch registra o diagnóstico de que "a batalha da UNESCO fracassou": "Constata-se hoje que as propostas da UNESCO de democratizar a comunicação ficaram no plano teórico, não interferindo efetivamente nas ações do Estado e no sistema produtivo dos meios de comunicação em massa." (KUNSCH, 2009, p. 61). Ela tem razão em termos. No ano em que Kunsch publicou seu artigo, a União Europeia estreou uma nova legislação de mídia, a Inglaterra avançava na redação da sua e a Argentina aprovava a ley de medios. Desde então, novos marcos regulatórios foram aprovados no Equador, na Venezuela e no Uruguai. No Brasil, revogou-se a lei de imprensa herdada do regime militar (2009), atualizou-se a regulação da TV a cabo (2011) e houve a promulgação do marco civil da internet (2014) e da nova lei de direito de resposta (2015).

Conceber o direito humano à comunicação implica entender os cidadãos que participam do sistema de comunicação como sujeitos de direitos. Neste sentido, é oportuno aprimorar o aparato de proteção, sobretudo em relação aos abusos cometidos pelas empresas de mídia: a violação do direito à privacidade, o crime de injúria ou difamação, a exploração da imagem de crianças e vulneráveis, entre outros.

Ao mesmo tempo, é fundamental que instâncias jurídicas e sociedade civil estejam preparadas para lidar com o tema do direito à comunicação. Novas legislações virão se somar às ferramentas disponíveis e ajudarão a avançar no sentido de um modelo de comunicação que tenha como princípio a ampliação da esfera pública (ou esferas públicas, no plural) para um sistema que estimule a participação popular, a representatividade regional, econômica, racial e de gênero, e que possa influenciar mais fortemente as ações do Estado no sentido da democracia.

Camilo Vannuchi é jornalista e doutorando pelo Programa de Pós Graduação em Ciências da Comunicação da USP. É membro do grupo de pesquisa "Jornalismo, Direito e Liberdade", filiado à ECA e ao Instituto de Estudos Avançados da USP.

camilovannuchi@usp.br 


\section{Referências}

ANCINE. Notícia regulatória: comunicação audiovisual sob demanda. 2016. Disponível em: http:// www.ancine.gov.br/sites/default/files/consultas-publicas/notícia regulatória CAvD para Consulta Pública.pdf. Acesso em: 15 mai. 2017.

NAÇÕES UNIDAS NO BRASIL. Brasil: Relatores da ONU e OEA sobre liberdade de expressão alertam para interferências na EBC e na CGU. 24 jun. 2016. Disponível em: https://nacoesunidas. org/brasil-relatores-da-onu-e-oea-sobre-liberdade-de-expressao-alertam-para-interferencias-na-ebce-na-cgu/ Acesso em: 9 jan. 2017.

BRASIL. Constituição Federal de 1988. $18^{a}$ ed. Brasília: Câmara dos Deputados, Coordenação de Publicações, 2002.

FISHER, D. O direito de comunicar: Expressão, informação e liberdade. São Paulo: Brasiliense, 1982.

FRANÇA, V. V. O objeto e a pesquisa em comunicação: uma abordagem relacional. In: MOURA, C. P.; LOPES, M. I. V. Pesquisa em comunicação: metodologias e práticas acadêmicas. EdiPUCRS, 2016, p. 153-174. Disponível em: http://ebooks.pucrs.br/edipucrs/Ebooks/Pdf/978-85-397-0803-1. pdf. Acesso em: 9 set. 2017.

HABERMAS, J. Mudança estrutural da esfera pública. São Paulo: Ed. Unesp, 2014.

KUNSCH, M. M. K. Políticas públicas de comunicação: a necessidade de um debate abrangente. In: CASTRO, D. (org.). Reflexão sobre as políticas nacionais de comunicação. Brasília: Ipea, 2009, p. 59-77.

LIMA, V. A. Regulação das comunicações: História, poder e direitos. São Paulo: Paulus, 2011.

LIMA, V. A.; GUIMARÃES, J.; AMORIM, A. P. (org.). Em defesa de uma opinião pública democrática: conceitos, entraves e desafios. São Paulo: Paulus, 2014.

LIMA, V. A.; RABELO, B. S. Monopólio ou oligopólio: contribuição ao debate. Observatório da Imprensa. Ed. 833. 13 jan. 2015. Disponível em: http://observatoriodaimprensa.com.br/ interesse-publico/_ed833_monopolio_ou_oligopolio_contribuicao_ao_debate/ Acesso em: 10 jan. 2017.

LOSEKANN, C. A esfera pública habermasiana, seus principais críticos e as possibilidades do uso deste conceito no contexto brasileiro. Pensamento Plural, n. 4, 2009, p. 37-57. Disponível em:

MAIA, R. C. M. Mídia e deliberação. Rio de Janeiro: Ed. FGV, 2008.

ONU. Declaração universal dos direitos humanos. 10 dez. 1948. Disponível em: http://www. direitoshumanos.usp.br/index.php/Declaração-Universal-dos-Direitos-Humanos/declaracao -universal-dos-direitos-humanos.html. Acesso em: 10 mar. 2017.

RAMONET, I. Meios de comunicação: um poder a serviço de interesses privados? In: MORAES, D. (org.). Mídia, poder e contrapoder: Da concentração monopólica à democratização da informação. São Paulo: Boitempo; Rio de Janeiro: FAPERJ, 2013, p. 53-70.

UNESCO. Many voices, one world. Londres: Kogan Page, 1980. 